\title{
TITLE INDEX OF VOLUME 9
}

\section{EDITORIALS}

\section{UNITED NATIONS ACTIVITIES}

UNEP

- Session of a Special Character

- Extracts from Opening Statements

- "Down to Business"

- Summary of General Debate

- Adoption of the Report

- 10th Governing Council

- Programme Performance (Sessional Committee I)

- The Environment Fund (Sessional Committee II)

Law of the Sea Treaty Adopted

UNCLOS III. A Viable Convention? (Lee Kimbal and Adolf R. Schneider)

UNISPACE ' 82 - Second UN Conference on the Exploration and Peaceful Uses of Outer Space

\section{OTHER INTERNATIONAL DEVELOPMENTS}

Conférence Industrielle Internationale sur l'Environnement A Propos d'un Eventuel Principe Pollueur-Payeur en Matière de Pollution Transfrontière

Red Sea Treaty

Amoco Cadiz Claim Before US Court

South Pacific Conference on the Human Environment

Acid Rain Conference

Pollution Transfrontalière: Colloque de Sarrebruck (Pascale Kromarek

Elizabeth Haub Prize

Legal Principles Adopted by the OECD Council (Henri Smets) Conservation of Species: The Need for a New Approach (Cyrille de Klemm)

\section{REGIONAL ACTIVITIES}

EC

- Cadmium Discharges

EC/Court of Justice

- Recent Judgments

\section{NATIONAL AFFAIRS}

USA

- Elizabeth Haub Foundation Established

-.. Endangered Species Act Extended

- National Oceans Policy

\section{$1,65,103$ USSR}

- Mining Decree

96

Spain

- L'Impact Prévisible de son Adhésion à la C.E.E. (Jean-Pierre Hannequart)

Ireland

- Bogland

\section{SELECTED DOCUMENTS}

\section{UN/UNEP}

- SSC: Nairobi Declaration

- The Environment in 1982: Retrospect and Prospect

- Draft Resolution on Special Commission Proposed by Australia, Austria, Denmark, Finland, Iceland, India, Japan, Mexico,

New Zealand, Norway, Spain, Sweden, and Yugoslavia

- Resolutions Adopted by the Governing Council

- System-wide Medium-term Environment Programme

- Programme Matters

- Environmentally Dangerous Chemical Substances and Processes with Global Impact

- International Programme on Chemical Safety

- Protection of the Ozone Layer

- Implementation of the Plan of Action to Combat Desertification in the Sudano-Sahelian Region

- Expansion and Implementation of the Regional Seas Programme

- Environmental Law

- Working Group of Experts on Environmental Law

- Third United Nations Conference on the Law of the Sea

- Follow-up to the Ad Hoc Meeting of Senior Government Officials Expert in Environmental Law

- Additional Resources for Dealing with Serious Environmental

Problems in Developing Countries

- Contributions to the Fund

- UNEP Statement at Unispace ' 82

EC

- Mercury Discharges 102

94 LOS

- The Schedule

- Agreement Concerning Interim Arrangements Relating to Polymetallic Nodules of the Deep Sea Bed

The Regional Convention for the Conservation of the Red Sea and Gulf of Aden Environment

- The Action Plan

South Pacific Regional Environment Programme 63

$\begin{array}{lr}\text { Acid Rain Conference } & 100\end{array}$

- Conference Conclusion and Recommendations 101

\section{AUTHOR INDEX OF VOLUME 9}

Hannequart, Jean-Pierre, 97

Kimball, Lee, 66

Klemm, Cyrille de, 117

Kromarek, Pascale, 88 v. Moltke, Konrad, 94

Schneider, Adolf R.H., 66, 104, 108

Smets, Henri, 110 